\title{
Charles Adams and the Controversy over Use of the Woman's College Library in Segregated North Carolina
}

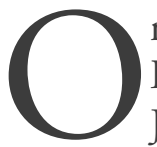
n November 13, 1950, Edward Kidder Graham Jr., the recently installed chancellor at the Woman's College of the University of North Carolina in Greensboro, (now the University of North Carolina at Greensboro), wrote a letter to his administrative counterparts at Bennett College and North Carolina Agricultural and Technical College, both African American institutions of higher learning also in Greensboro. In the letter, he issued an open invitation for these leaders as well as other faculty members and student body representatives to attend the upcoming Harriet Elliott Social Science Forum titled "Public Opinion in a Democracy." Graham stated that "the round table sessions on Friday afternoon are for faculty and student representatives of participating institutions, and all seats are open to all delegates at these round table sessions. On the other hand for the general meetings in Aycock Auditorium at public events, and in accordance with the policy of the Consolidated University, we shall have to ask those of our guests who are Negroes to sit in a section reserved for them."'

While Greensboro is well known as being a center of activity for the civil rights movement since the February 1960 student-led sit-ins at the downtown Greensboro Woolworth's lunch counter, ten years prior the city and its centers of higher education were strictly segregated. The Woman's College (WC) existed to educate white females, and the Jim Crow laws that were instituted in the late nineteenth and early twentieth centuries were firmly entrenched on the WC campus as in the rest of American society.

Yet, on the WC campus, a handful of faculty and staff worked together to promote opportunities for sharing among the Greensboro area campuses and students, regardless of race. Offcampus meetings with administrators and students at the neighboring African American institutions began in the 1920s. Use of the WC facilities for such meetings, or for any purposes by the students or staff of these African American colleges, was strictly forbidden by state law.

Debates over rights to access to library resources, however, became particularly contentious in the early 1950s when administrators from the University of North Carolina Consolidated System stepped in to attempt to halt any use of campus resources by African American students from neighboring colleges. Issues of race, gender, and information access came together to force the Woman's College Library to reconsider some little-known practices which allowed open access to the library resources by all students, regardless of race or gender.

\section{Library Development at the Women's College}

Since its 1892 opening, the State Normal and Industrial School for White Girls (later Woman's College) featured a library collection intended to enhance student learning. The library was initially housed in a single room in Main Building, the administrative and academic hub of the early campus. In 1898, Annie Petty (who began work as the campus librarian in 1895) completed study at the Drexel Institute Library School in Philadelphia and became the first professionally-trained librarian in North Carolina. By 1900, Petty had grown the library collection to around 3000 volumes. When the school's new library building, funded by philanthropist Andrew Carnegie, opened in 1905, the collection had grown to more than 5,000 books.

Growth continued, but in 1932, much of the library building was destroyed by fire (although the books themselves survived with only water damage, as the stacks were fireproof). Although a full restoration of the Carnegie library was completed within a year, the building quickly became overcrowded. In 1939, the College Librarian, Guy Lyle, called for a new building. Construction was delayed due to World War II, but by the late 1940s, it became clear that a growing library collection and increasing student body population demanded a new library facility. The next College Librarian, Charles $\mathrm{M}$. Adams, arrived in September 1945 to a collection that had grown exponentially in size since moving in to its home, reaching 134,000 volumes in 1948.

Adams, a native of LaMoure, North Dakota, arrived at the Woman's College from Columbia University, where he had served 
for seven years as Assistant to the Director of Libraries. When he began, one of his first jobs was to help plan a new library building to house the WC's growing collection. The Winston-Salem-based firm Northrup and O'Brien was selected to design and build the new facility, which began construction in October 1948. In June 1950, the campus's new library building opened and circulation numbers jumped from 89,615 in $1948-1949$ to 107,776 in 1950-1951. ${ }^{2}$

Not all of these library users, however, were WC students. Some were alumnae, others were townspeople, and still more were students from neighboring colleges. In fact, circulation of WC books to students from other colleges skyrocketed with the opening of the new library facility, going from 501 in 1948-1949 to 2,651 in $1950-1951.3$ In his annual report written only months after moving into the new library building, Adams observed that "the growth of library service beyond the central building should be watched and understood clearly." He feared that increased traffic from and lending to non-WC students would lead to a lack of needed resources for the WC women themselves. Books might be unavailable to meet a WC student's needs, and, as Adams noted, "funds have not been allotted to take care of duplicates necessary to set up reserve collections where they are not available for general use of students." 4

Greensboro College, which sat between the WC campus and downtown Greensboro, was at the time a privately-supported woman's college (now coeducational). Guilford College, located west of WC, was a small Quaker institution educating men and women. Bennett College educated African American women, primarily focusing on teacher training. The largest local institution (aside from WC), however, was North Carolina Agricultural and Technical (A\&T) College (now University), a land-grant institution and publicly-funded college for African American men and women. North Carolina A\&T also supported teacher education for African Americans, and its summer school program proved particularly popular with local educators. Each of the neighboring institutions was smaller than WC, but many offered similar academic programs, leading to numerous opportunities for collaboration as well as potential sharing of resources. It was the sharing of library resources with students from North Carolina A\&T that spurred the most controversy among both local campus and state-level University of North Carolina Consolidated System administrators.

\section{Women's College Library Use by African American Students}

While library use by non-WC students skyrocketed with the opening of the new library building in 1950, this did not mark the first time that college administrations had faced questions regarding facility use by students from neighboring colleges, including the nearby African American institutions. As early as February 1929, administrators were discussing use of the Library by students from North Carolina A\&T. Then Vice President (and later Chancellor) Walter Clinton Jackson wrote College President Julius Foust requesting that an $\mathrm{A} \& \mathrm{~T}$ student be allowed to borrow books from the Women's College Library. Jackson wrote, "it seems to me rather incongruous that we should refuse a little courtesy of this kind to a neighbor institution, even though a negro institution. It is a very small matter, in a way, but it has large consequences so far as the Negroes are concerned." Foust agreed to discuss the matter with the College Librarian and "do anything we can to aid these students." He quickly added, however, that Jackson should be acutely aware "that certain embarrassments may arise in our attempt to do what they request" and that he "doubt[ed] the wisdom of permitting negro students to take the books out of our library." While he agreed to consider the idea, Foust added that he would ask the Librarian to consult with Dr. Anna Gove, the student health coordinator, to learn more "about the danger that may arise from disease if these students are permitted to take the books and use them when our students must use them when they are returned to the library." 6

Jackson's decision to support the use of the WC Library by African American students ran counter to the Jim Crow laws that were prevalent across North Carolina at the time. Jackson, however, was well known as a champion of racial equality. He arrived at State Normal in 1909 to lead the History Department. A native of Georgia, he studied at Mercer University and spoke frequently on the topic of race relations in American history. Although he was forced to work within the framework of the segregated South, he served as chairman of local, state, and southern regional Commissions on Interracial Cooperation. From 1938 to 1953 , he served as chairman of the Board of Trustees at Bennett College, Greensboro's college for African American women. In presenting him with an honorary doctorate in 1949, Bennett referred to Jackson as a "pioneer in the field of better race relations." 7 
Throughout his sixteen-year tenure as Woman's College Chancellor (1934-1950), Jackson opened many venues for progress and collaboration between WC and its neighboring educational institutions, including African American. In a June 17, 1935 letter to Charlotte Hawkins Brown, he expressed dismay that WC would not be able to openly welcome students from Brown's Palmer Institute, a school for African Americans in Sedalia, North Carolina, just outside of Greensboro. After Brown declined to bring her students to a music performance at the WC due to the segregated seating requirements, Jackson wrote, "I hope the time will speedily come when difficulties which confront us may be more easily resolved."

State laws and regulations, however, did not support open sharing of resources between WC and its African American neighbor institutions. "Separate but equal" policies resulted in the segregation of public schools, public spaces, transportation, restrooms, restaurants, and drinking fountains. Since 1901, North Carolina state law had explicitly required separate facilities for the consumption of library materials by white and black citizens. ${ }^{9}$ While a number of prominent North Carolinians, including Governor W. Kerr Scott (1949-1953), believed in extending some degree of civil liberties to African Americans, the general consensus across the state favored the continuation of segregationist policies.

WC Librarian Charles Adams, however, favored allowing access to WC Library materials for students at neighboring colleges, including those at African American institutions. Having grown up in North Dakota, he was not entrenched in the southern Jim Crow laws. While he admitted to not knowing any African Americans personally before arriving in Greensboro, his subsequent actions reflected a desire to assist and work with African Americans. At the reception celebrating the opening of the new library building, Adams purposefully scheduled a tea instead of a formal sit-down dinner reception for guests, as a sit-down meal would have excluded his African American librarian counterparts from North Carolina A\&T and Bennett. ${ }^{10}$ Similarly, he successfully lobbied for a joint meeting of the North Carolina Library Association and the North Carolina Negro Library Association in 1951, again forgoing the traditional banquet meal in favor of a more inclusive meeting. ${ }^{11} \mathrm{He}$ continued allowing African American students from neighboring campuses to borrow WC library books, a practice that quickly brought him in conflict with WC and Consolidated System administrators in the early months of 1951.

\section{The 1951-1952 Controversy over Library Use}

On February 6, 1951, John W. Clark wrote a brief letter to Woman's College Chancellor Edward Kidder Graham Jr. Clark, a segregationist leader, had recently been appointed by Governor Scott to serve on the Admissions Committee of the Board of Trustees. He wrote asking for a list of names of faculty members who were in favor of integration. Clark stated, "If you would be kind enough to let me know who the individuals are who wish to discontinue segregation at college meetings and the departments with which they are connected I will appreciate it. I trust they have no desire to keep the matter secret." 12 Graham, who had been chancellor for less than a year, wrote UNC Consolidated System President
Gordon Gray for his opinion on a draft response, noting that "the burden of all this falls ultimately on [the System President]."13

Gray issued the first response to Clark's query, blind copying Graham as well as Woman's College alumnae and UNC Trustee Laura Cone. Gray expressed a desire to "deal with the problem within the administration," stating that he did not "see any real value in making an official designation of the people who I believe are interested in this problem." ${ }^{14} \mathrm{He}$ emphasized that faculty who spoke out in favor of integration were doing so in a way that broke no regulations and without abusing their positions. Graham's response to Clark echoed the same sentiment. While he admitted that many faculty opposed segregation, he noted that no one had presented him with a petition or spoken to him directly on the matter. He added, "I am confident that you and I are in full agreement on the point that what a man thinks is his own business." He did add, however, that viewpoints that resulted in "slanted teaching," "action contrary to the interest of the College or contrary to policy established by the Trustees," or "membership in any organization which by its nature is committed to the subversion of our free government" would represent "irresponsibility on the part of the individual" and would not be tolerated. ${ }^{15}$

While Graham declined to provide Clark with the specific names of those members of the faculty who supported integration, he did begin a closer examination of College policies related to African American use of campus facilities and resources. He found that the Library continued the previously-established practice of allowing limited use by African American students from neighboring 
colleges, and that Adams had recently conducted an internal discussion with his staff regarding use of the Library by African Americans. to Adams. Graham expressed concern that the issue would continue to grow and that, with a current policy in place, any change would quickly program at Bennett College were given full tours of the Library facilities. Reference services were "given liberally on request and considerable

\section{G6... Graham wrote a tense letter outlining what he saw as the leading issues related to the use of Library resources by African Americans and chastising the librarian for his decisions to construct and apply Library policy without first consulting the chancellor. 9}

After a face-to-face meeting with Adams in early April 1951, Graham wrote a tense letter outlining what he saw as the leading issues related to the use of Library resources by African Americans and chastising the librarian for his decisions to construct and apply Library policy without first consulting the chancellor. Graham argued that it was Adams' responsibility to bring this matter to his attention before creating an internal policy, stating that "any procedure or practice, or any policy question, bearing on the use of College facilities by Negroes should be brought to my attention." He added that any policies relating to use of College facilities must conform to Trustee regulations, and that, because Adams did not involve him in the discussion regarding use policy sooner, "we now find ourselves in an unhappy position where the College could bring embarrassment to President Gray at a time when he is engaged in the thankless assignment of trying to bring some measure of order and equity into racial relations in higher education in this State." In advance of President Gray's April 15 visit to Greensboro, Graham requested that Adams construct a "concise memorandum on the policies and procedures that [the Library] wants to follow in respect to the use of the Library by Negroes." ${ }^{16}$

Graham followed with a memo to Gray, including a copy of his letter be attributed to "racial prejudice." Yet, not changing the policy might put the Library and the College at odds with Consolidated University policy and the desires of the Trustees. He noted, "we have a chance of getting out of this thing with a whole skin, but it is not much more than a chance." ${ }^{17}$

Two days after receiving Graham's letter about the Library's policy, Adams crafted a response that outlined the existing (although undocumented) Library policy regarding use by African Americans. Adams noted that the stated procedures had been consistently followed for many years, although they had never been formalized in writing. He added that "these practices represent the position the staff wants and is happy to take so far as it concerns the use of the Library by Negroes." 18

In his April 12, 1951, "Memorandum on the Use of the Library by Negroes," Adams describes a Library that is relatively open to African Americans - both students and faculty at neighboring colleges and a few community members. Full access to the public catalog as well as use of books from the closed stacks (via call slip), from the open shelves in the reference and periodical rooms, or through interlibrary loan was permitted. Visiting African American librarians from neighboring colleges and students in the Library Training effort has been made to help them graciously and fully in locating material for their study or research." Only the reserve reading room, which housed required reading for WC students, was not open to use by the African American visitors. ${ }^{19}$

In spite of the liberal use policy, Adams emphasized that use of the library facilities by African Americans was very rare. While the Library did not maintain statistics to document use by African American visitors, he did admit that he observed a small increase after moving into the Library's new building. He estimated that around six or seven African Americans consulted the public cata$\log$ and two or three made use of the reading room facilities each week.

Graham forwarded Adams' memorandum to President Gray in Chapel Hill, and requested that Gray meet with Adams and the Library staff during his upcoming visit to Greensboro. That meeting never took place due to Gray's schedule, but Graham continued to ask Adams for updates on use patterns and any policy changes related to African American use of the Library. He also requested that Adams more heavily emphasize that use of the WC Library facilities should be limited to students who have a documented need for a book that his or her home library cannot provide. This, he hoped, would reduce the total number of visitors, African American or 
otherwise.

Through the remainder of the Spring 1951 semester, use of the Library by African Americans remained low, with a total of 58 users between April 15 and May 29. But as summer school began, the number dramatically increased. In one week (June 8-13), 41 African Americans, primarily female students enrolled in a teacher training program at North Carolina A\&T, visited the Library. Adams noted that "many of these students are requesting reference service and help in developing theses requiring work in the library." He added that the library instituted the practice of beginning these interactions by markedly asking the student whether he or she had already exhausted the facilities of his or her home library. ${ }^{20}$

Use of the new library facilities by African Americans continued to increase, however, and Adams was forced to develop a more formal approach to limiting access. While Graham sought a formal policy specifically restricting African American use of the library facilities, Adams notably avoided creating a policy that specifically targeted only those students who were African American. Adam's newly-developed policy more uniformly limited access to the Library for all non-WC college students. Thus Adams insured that use of the WC Library by non-WC students would continue, but only with a new requirement in place: All students from outside of the Woman's College would now be required to present a letter of introduction or a card of identification from their home institution's library.

The librarian at Bennett College observed this practice by telephoning the WC Library prior to a Bennett student's visit. ${ }^{21}$ Alma Morrow, Librarian at North Carolina A\&T, willingly instituted the requirement at her library after a number of A\&T students borrowed books from the WC Library without returning them. She specifically requested that Williams and the WC Library staff "check out books in the future only to students who present a letter to you from A\&T Library." 22 Adams agreed to the practice, and suggested extending the requirement to students with reference queries as well as those borrowing books. He stressed that he did not "believe that many, if any of your students, have abused this privilege, but it would help us to know that they had already talked with you before coming out here." But he added that use numbers had grown greatly over the past year, and particularly over the summer, and that "some of these students might have saved a trip for themselves by first consulting with you." 23

In a July 5, 1951, letter to the librarians at Greensboro College, Guilford College, North Carolina A\&T College, Bennett College, Immanuel Lutheran College, and Greensboro Evening College, Adams announced that the WC Library would now require all non-WC students to present a letter or card of identification from their home institution's librarian. Students would be required to check with their college librarian prior to visiting the WC Library for any purpose (borrowing, reference, etc.). Adams argued that "we think this regulation would not only be of help to us but also to you in your guidance of student use of the library." ${ }^{24}$ The policy would be in place for all non-WC students, regardless of race.

This new requirement satisfied Graham, who announced to President Gray in October 1951 that use of the Library by "outsiders" had been greatly reduced. He noted that "apparently it was the attraction of our excellent library facilities, rather than the absence of the required books in other college libraries, that was in considerable measure responsible for the increase in outside use which was noted during the past spring and summer." ${ }^{25}$ Graham wrote to Adams that "to the best of my knowledge we are [now] complying with the policy of the Board of Trustees and University Administration." 26 Logan Wilson, UNC Vice President, concurred with Graham. In a memorandum to President Gray, he called the procedure "a sensible way to handle the problem," and suggested that State College in Raleigh might adopt a similar policy. ${ }^{27}$ Adams' policy of a uniform restriction, regardless of race, was a way for campus and university administrators to limit use of the facilities by outsiders, while not explicitly creating limitations due to race.

Throughout the discussions in 1951, The Carolinian, the WC's student newspaper, made no note of the debates. It was not until February 22,1952 , that the student newspaper took note, reprinting a year-old letter Clark wrote to local officials in Four Oaks and Maxton, N.C., requesting information on local students he labeled as subversive and anti-segregationist. Specifically, he wished to know if these students came "from a family who advocates and practices this sort of thing" or if the students were "imbued" with these ideas while enrolled in the UNC Consolidated System. The Carolinian, however, took particular umbrage at Clark's statements about WC, where he wrote that "there is also a considerable number of individuals ... who advocate this same sort of thing." The article sought to disprove several factual errors in Clark's statements (which The Carolinian referred to as "fiction 
of purest ray serene"), and asked for formal clarification of Clark's involvement and any authorization he may have had from Governor Scott or the UNC Board of Trustees in writing the letters or discussing segregationist policies with non-UNC audiences. The Carolinian argued that Clark's actions made "the Board of Trustees and the University appear ludicrous in the eyes of North Carolinians who look to the University and its trustees to uphold the University tradition of responsibility, integrity, good taste, and common decency." They called upon the Board to pass a resolution clarifying that Clark's queries were not being conducted in his role as Trustee. ${ }^{28}$ At its February 29 meeting, the Board officially censured Clark, stating that "it is the view of the Board of Trustees of the greater University of North Carolina that the statements and declarations of $\mathrm{Mr}$. John W. Clark and his controversy with others concerning segregation and racial questions are his own responsibility and the Board deems it inappropriate for it to take official recognition of such matters." ${ }^{29}$

At the same February 29 meeting, however, Clark continued his assault on Woman's College, criticizing two students for attending an interracial religious meeting at a Greensboro church (arguing that they were "hanging around inside the church with the Negro men for more than an hour after the services") and lambasting the school for inviting "atheist" speakers such as Bertram Russell to campus. ${ }^{30} \mathrm{He}$ also once again argued against use of the WC Library by African Americans, proposing a movement "that the Woman's College Library be reserved for the students for whom it was built, and that if the Negro students do not have a sufficient library, one be built for them." ${ }^{11}$ Trustee Laura
Cone, a graduate of WC, pointed out the existing policy that required all non-WC students to present documentation from his or her own college librarian stating the student's research needs. But, the remaining Trustees voted to refer the issue to the Executive Committee (which no longer included Clark) and request a full report at their meeting on April 19.

In early March, the chancellors from WC as well as the University of North Carolina at Chapel Hill and State College requested copies of their library's policies regarding use of the library by African Americans. The other two schools reported policies that were similar to, but slightly more restrictive than those practiced at WC. In Chapel Hill, Director of Libraries Charles E. Rush reported that African Americans were allowed full use of the catalog and indexes. Temporary stack permits would be issued if the researcher had a documented need, and a special carrel would be assigned if extended study time was needed (thus freeing table space in the readings rooms for UNC students only). Lending, however, was allowed only through interlibrary loan or the Library Extension Department. State College Librarian Harlan C. Brown reported the same restrictions at his institution, adding that use of resources within the library building itself was freely available to all researchers regardless of race. $^{32}$

Instead, Adams once again avoided producing a policy with constraints solely based on race. He formalized the restrictions on use of the WC Library by students at neighboring colleges in a March 24, 1952, memorandum titled "Statements of Policy and Regulations Governing the Use of Library materials by Non-College Persons." This memorandum was compiled from an existing staff manual as well as letters between Adams, Graham, and other local librarians. The policy began by emphasizing that "the Library of the Woman's College of the University of North Carolina is maintained essentially for the use of its students and faculty. By courtesy, certain services and resources are available to Woman's College alumnae, townspeople, visiting students and scholars, and to other people who have special needs for its resources." 33

The policy never specifically placed any restrictions on use by African Americans, students or nonstudents. Instead, it required all people who were not WC students or alumnae to present clear evidence of their need for the use of the WC Library. As noted in Adams' letter from the previous summer, the policy required students from other colleges in Greensboro to "present a card or letter from their librarian requesting books or services not available at their institution." Unlike the policies at State College and Chapel Hill, the WC policy allowed non-WC students - regardless of race - to borrow books as long as they provided the required letter of need from their home institution. ${ }^{34}$

This policy, however, did not satisfy Graham, who followed up by specifically demanding information on the use of the library by African Americans. Adams responded with a one-page memorandum with an attached timeline of specific requests for use by African Americans during the 1951-1952 academic year. As in his report created a year previously, he began by noting that "the use of the Woman's College Library has been available with certain restrictions to Negroes for a great many years." He detailed the policy requiring students to present a letter or card from their 
home institution, and mentioned a few instances of use of the Library by African Americans who were not students (primarily faculty members at local colleges). He noted only two requests from African American townspeople - one doctor and one minister's wife - and stated that "reasonable requests of this type have been filled." 35

At Graham's insistence, Adams added a restriction against any use of the library by non-WC students after 5:00 p.m. Graham noted that afterhours use of the Library by non-WC students "is not a Negro problem but one concerning the primary function of the College." 36 Adams argued that the situation at the time did not warrant this type of limitation, but admitted that "the regulation can be justified as desirable in anticipation of a growing demand on the part of the public." 37 He agreed to add the restriction, with the stipulation that the librarians or library staff be given discretion in allowing exemptions for any individuals who may need them.

This final policy with the restriction to use during business hours only was approved by the Faculty Library Committee in a 5-2 vote. English professor Marc Friedlaender, a vocal supporter of racial equality, voted "yes," but added that he would like his vote to "carry with it too my understanding that the interpretation of the revised policy by the staff will be the broadest and most generous consistent with the spirit of our discussion." $\mathrm{He}$ also requested that records be kept and reports to the Committee be made documenting "all instances where the facilities of the Library were refused to any individual." 38

On May 12, 1952, Graham took the finalized policy for use of the library by non-WC students to the Executive Committee of the Board of Trustees. His report, along with reports provided by his counterparts at State College and UNC Chapel Hill, was presented by President Gray. Trustee Laura Cone made the initial motion to close the investigations, stating that "the Executive Committee is satisfied that the use of the library by Negroes is properly restricted and conducted at the three institutions." ${ }^{39}$ With that, the major discussion of the issue at the Board level was resolved. Restrictions against library use by non-WC students were formally and firmly in place, but were to be equally applied to all non-WC students, regardless of the patron's race.

\section{Conclusion}

Discussion on the campus level over use of library resources by students from North Carolina A\&T continued for years to come. In the Spring of 1953, Library staff began tracking use of the WC Library by students from each of the local colleges. ${ }^{40}$ As the 1954-1955 Annual Report noted, "the use of the Library by non-college readers has shown little change, in fact the figures are actually showing a decline. This service has never been advertised or promoted." ${ }^{11}$ Use by North Carolina A\&T students actually dropped dramatically in the 1955-1956 academic year (from 53 in $1954-1955$ to 15 in $1955-1956$ ), as their librarian began refusing to provide letters to permit student use of the facilities after a number of students failed to return borrowed WC books. ${ }^{42}$

Even after the WC itself was integrated in the Fall of 1956, rumors of heavy use of the WC Library by North Carolina A\&T students continued to concern some administrators and alumnae. Two years after WC's desegregation, an alumna approached the new chancellor, Gordon Blackwell, with a rumor "to the effect that numerous students from A. and $T$. College have been using our library, that this has caused problems with our students, and that guards have had to be employed to control the situation." Blackwell quickly investigated and reported back on the Library policies developed in $1952 .{ }^{43}$ He noted that "since the use of the Woman's College Library by students from Negro colleges has been rapidly declining since 1953 and is approaching the vanishing point, perhaps because of the strengthening of their libraries, and since we know of no social comingling which has arisen under our present regulations, I am confident that the situation is well under control." ${ }^{44}$

The debate over African American use of Woman's College resources touched upon many key topics prevalent in North Carolina in the 1950s. While administrators of the Consolidated System fought against desegregation and the forced admission of African American students to the University campus in Chapel Hill in 1951, Charles Adams and the librarians of the Woman's College stepped forward to commit to access to information and Library resources, regardless of the color of the patron's skin.

Issues of race and gender were intermingled, and much of the debate over who should be allowed to access WC Library resources took place mostly away from the WC campus. Discussions and debates took place largely on the Board of Trustees level, with WC Chancellor Graham serving as the messenger and retriever of information for the Board members. While limitations to Library use were put in place by these administrators, Adams and his staff ensured that the restrictions were equally applied to all non-WC students, promoting 
access to information for all in need, regardless of race.

\section{References}

1 Edward Kidder Graham Jr., to David B. Jones, November 13, 1950; Graham to F.D. Bluford, November 13, 1950; Edward Kidder Graham, Jr., Records, Martha Blakeney Hodges Special Collections and University Archives, The University of North Carolina at Greensboro, NC, USA.

2 "Annual Report of the Librarian, 1949" and "Annual Report of the Librarian,” 1951. Dean of University Libraries Records, Martha Blakeney Hodges Special Collections and University Archives, The University of North Carolina at Greensboro, NC, USA.

3 Ibid.

4 "Annual Report of the Librarian," 1950. Dean of University Libraries Records.

5 W.C. Jackson to Julius Foust, February 12, 1929. Julius I. Foust Records, Martha Blakeney Hodges Special Collections and University Archives, The University of North Carolina at Greensboro, NC, USA.

6 Foust to Jackson, February 15, 1929. Julius I. Foust Records.

7 Degree citation, May 30, 1949. Walter Clinton Jackson Records, Martha Blakeney Hodges Special Collections and University Archives, The University of North Carolina at Greensboro, NC, USA.

8 Jackson to Charlotte Hawkins Brown, June 17, 1935. Walter Clinton Jackson Records.

9 The General Statutes of North Carolina in 1901 directed the State Librarian to "fit up and maintain a separate place for the use of the colored people who may come to the library for the purpose of reading books or periodicals" (General
Statutes, North Carolina, 1901: 125-10). A 1930 North Carolina Supreme Court ruling explicitly applied the "separate but equal" policy to library facilities, noting that "It has long been the settled policy of this State, promulgated through the legislative branch of the government, to have separation or segregation of the white and negro races with equal accommodations" (Corporate Commission v. Transportation Committee of the North Carolina Commission on Interracial Co-operation, 19 N.C. 317 (1930)). North Carolina was the only one of the 13 Jim Crow states which had such a law officially segregating its state library.

${ }^{10}$ Oral History interview with Charles M. Adams and Ellen Adams, April 6, 1990. UNCG Centennial Oral History Project Collection, Martha Blakeney Hodges Special Collections and University Archives, The University of North Carolina at Greensboro, NC, USA.

${ }^{11}$ Adams to Harlan Brown, February 12, 1951. Dean of University Libraries Records.

12 John W. Clark to Graham, February 6, 1951. Edward Kidder Graham Records.

${ }^{13}$ Graham to Gray, February 9, 1951. Edward Kidder Graham Records.

${ }^{14}$ Gordon Gray to Clark, February 9, 1951. Edward Kidder Graham Records.

${ }_{15}$ Graham to Clark, February 17, 1951. Edward Kidder Graham Records.

${ }^{16}$ Graham to Charles Adams, April 10, 1951. Edward Kidder Graham Records.

${ }^{17}$ Graham to Gray, April 11, 1951. Edward Kidder Graham Records.

${ }^{18}$ Adams to Graham, April 12, 1951. Dean of University Libraries
Records.

19 "Memorandum on the Use of the Library by Negroes," April 12, 1951. Dean of University Libraries Records.

${ }^{20}$ Adams to Graham, June 14, 1951. Edward Kidder Graham Records. Also of note, Adams mentions a lack of separate restroom facilities for the African American researchers. Previously, these visitors had used a student lounge located on the ground floor of library, but Adams notes that "we feel that this might be undesirable because of the large number of older students in our summer school who might question the Negro use of the student lounge." Therefore, he requests permission from Graham to allow African American female visitors to use the restroom facility on the main floor that was typically reserved for staff use only.

${ }^{21}$ Adams to Graham, October 20, 1951. Dean of University Libraries Records.

${ }^{22}$ Alma I. Morrow to Sue Vernon Williams, June 28, 1951. Dean of University Libraries Records.

${ }^{23}$ Adams to Morrow, June 30, 1951. Dean of University Libraries Records.

${ }^{24}$ Adams to College Librarians, July 5, 1951. Dean of University Libraries Records.

${ }^{25}$ Graham to Gray, October 23, 1951. Edward Kidder Graham Records.

${ }^{26}$ Graham to Adams, October 24, 1951. Edward Kidder Graham Records.

${ }^{27}$ Logan Wilson to Gray, December 17, 1951. Edward Kidder Graham Records.

28 "John W. Clark Rides Again," The Carolinian, February 22, 1952, 1.

${ }^{29}$ Meeting minutes, February 29, 1952, Consolidated University Cabinet Records, Martha Blakeney 
Hodges Special Collections and University Archives, The University of North Carolina at Greensboro, NC, USA.

30 "UNC Board of Trustees

Reprimands Clark; WC Receiver of Numerous Clark Charges," The Carolinian, March 7, 1952, 1.

${ }^{31}$ Meeting minutes, February 29, 1952 Consolidated University Cabinet Records.

${ }^{32}$ Charles E. Rush to Robert Burton House, March 12, 1952. Harlan C. Brown to J.W. Harrelson, March 18, 1952. Edward Kidder Graham Records.

${ }^{33}$ Statements of Policy and Regulations Governing the Use of Library Materials by NonCollege Persons, March 24, 1952, Faculty Library Committee Records, Martha Blakeney Hodges Special Collections and University Archives, The University of North Carolina at Greensboro, NC, USA.
${ }^{34}$ Ibid.

${ }^{35}$ Adams to Graham, April 4, 1952. Edward Kidder Graham Records.

${ }^{36}$ Meeting Minutes, April 14, 1952. Consolidated University Cabinet Records.

${ }^{37}$ Adams to Members of the Faculty Library Committee, April 22, 1952. Faculty Library Committee Records.

${ }^{38}$ Adams to Graham, April 28, 1952. Edward Kidder Graham Records.

${ }^{39}$ Meeting Minutes, May 12, 1952. Consolidated University Cabinet Records. Of note, in a May 27, 1952, letter to Governor Scott included as an addendum to the meeting minutes, President Gray corrects the recorded meeting minutes, stating that "it was clear after very considerable discussion that the resolution not use the word "Negroes," but would refer to use of the libraries by [those] other than faculty, staff, and students. It was also clear that the word "restricted" would not appear in the resolution."

${ }^{40}$ Previously, the use statistics for non-WC students had simply been reported as a total number, not broken down into individual institutions.

41 “1954-1955 Annual Report.” Dean of University Libraries Records.

${ }^{42}$ Adams to Graham, January 17, 1956. Dean of University Libraries Records.

${ }^{43}$ Blackwell to Buxton Midyette, November 12, 1958. Gordon Blackwell Records, Martha Blakeney Hodges Special Collections and University Archives, The University of North Carolina at Greensboro, NC, USA. ${ }^{44}$ Blackwell to Mrs. J.B. Kittrell and Mr. Hill Yarborough, November 12, 1958. Gordon Blackwell Records.

\section{Submission requirements for North Carolina Libraries}

Eletronic articles can be submitted online at http://www.ncl.ecu.edu.

- To submit you must login; if needed you can register using the link in the header.

- We use the Chicago Manual of Style (15th edition, 2003).

- We have a rolling deadline, articles are juried when received.

- Publication of approved articles is in about 3-9 months depending on space available.

- For additional information, contact Ralph Scott scottr@ecu.edu. 